water resources in a region, and providing estimates of usable water supply. Attention is given to methods which are adapted for use in the absence of adequate hydrological data and to simple techniques of observing hydrological phenomena which may provide useful data with least cost in time and money. Despite the importance of ground-water circulation in all regions-and especially in arid regions--the survey is limited to the discussion of techniques with regard to surface resources. These are a guide to the estimation of requisite rates of replenishment of ground water that are necessary for the effective use of the latter over a period of time. The main topics discussed are the hydrological balance, precipitation, evapotranspiration and its measurement, stream-flow, sediment transport and water supply, and a summary direction for procedure in the matter of water-resource surveys.

The special problems and peculiar needs of a densely populated and highly industrialized country such as Great Britain are summarized in an interesting discussion on a water-use survey opened by Prof. W. G. V. Balchin (under the chairmanship of Prof. Dudley
Stamp), with contributions from experts representing a very wide range of technical interests in this important field (Geog. J., 124, 476; 1958). Prof. Balchin directs attention to the dramatic increases in water consumption in Britain during the past century, culminating in an increase of 50 per cent in England and Wales and 41 per cent in Scotland during the short period 1938-56. The water storage capacity in the same time has increased by only 46 per cent and 31 per cent, respectively. The area where the consumption is greatest is the area where population is densest and the rainfall least, and where the local resources are already fully omployed-that is, in lowland Britain and particularly in the great urban and industrial complexes.

These papers are a salutary reminder, through the many facets to the problem of water conservation that they reveal, of our ultimate dependence on water resources and our need to avoid over-exploitation of a raw material that, in Great Britain at least, people assume all too readily is in abundant supply, and for which in many others the supply is already precarious.

AT,ICE GARnewT

\title{
CARNEGIE TRUST FOR THE UNIVERSITIES OF SCOTLAND
}

\begin{abstract}
$\mathrm{T}$ HE fifty-seventh annual report of the Executive Committee of the Carnegie Trust for the Univer. sities of Scotland covers the year 1957-58 (pp. iv +74. Edinburgh : Carnegie Trust for the Universities of Scotland, 1959) and includes the financial accounts for the year ended September 30, 1958. A major preoccupation of the Executive Committee during the year was the formulation of a policy to implement its new powers of investment. During the year there were on the books five senior research scholars, thirty-six research scholars in their socond or third year, and twenty-five in their first year. For 1958-59 the value of the senior scholarship has been increased to $£ 500$ (with an additional $£ 100$ for expenses), while scholars at Oxford, Cambridge and London will receive $\$ 450$; scholars living away from home, attending a Scottish or an English provincial university, $£ 400$; and scholars living at home and attending a Scottish university, $£ 350$. A grant of $£ 4,000$ a year for five years from the end of 1958 was made to the Scottish Dietionaries Joint Council, subject to some conditions with regard to progress. Ten of the research grants awarded during the year were for expenses involved in illustrating the published results of research and five grants were made to authors as a subvention towards the cost of publishing their books.

Four grants are particularly mentioned. The Trust has provided a special heavy-duty vehicle and a 'Folboat' with outboard motor and a grant for running expenses to assist Prof. J. H. Burnett and Dr. D. H. N. Spence, of the University of St. Andrews, in preparing a comprehensive account of the aquatic vegetation of Scotland, a research which involves crossing many moorland roads to examine distant mountain lochs. A grant of $£ 2,500$ was made to Prof. R. H. Matthew, of the University of Edinburgh, for a study by a research team correlating the problems of the design of basic dwelling units, lay-out, siting and services
\end{abstract}

with social requirements, with specific reference to contrasting types of social grouping and including a cost study. Another grant was to the University of Glasgow North Rona Expedition, which spent about a month on North Rona and Sula Sgeir, paying particular attention to marine biology. Some very rare species of algae were found and a special census was made of Leech's petrel. A second successful expedition, assisted by a grant from the Trust, was one from the University of Aberdeen, led by Prof. A. C. O'Dell, to St. Ninian's Isle, Shetland, in June-July 1958, in which a most important collection of silvor ornaments was uncovered.

Of the ten grants for travel and maintenance made to members of university staffs engaged in research, three were to members of a faculty of medicine, four in science and three in arts. Among these may bo mentioned those to Dr. W. I. Card to enable him to visit centres in the United States and Canada, where work of interest and importance in gastroenterology is proceeding; to Mr. Alastair Fraser, to work in Copenhagen in the laboratories of Prof. M. Thomsen and Dr. E. Thomsen, leading authorities on insect endocrinology, and later in Liège, Brussels and Paris; to Dr. C. H. Gimingham to enable him to follow up in Scandinavia his investigations in Scottish heaths, aimed at gaining a comprehonsive picture of the ecology of heather, including its reactions to grazing and burning and influences of soil climate and at utilizing this information in an investigation of the ways in which heath lands have originated and are maintained; to Dr. Elizabeth D. Fraser, to enable her to test in America some of her hypotheses regarding perceptual constancy as a function of personality and learning and the effect of metabolic disturbance ; and to Dr. P. H. Tuft, to diseuss his experimental techniques in embryology in the United States. 